\title{
ANALISIS LITERASI KEUANGAN MAHASISWA S-1 FAKULTAS EKONOMIKA DAN BISNIS UNIVERSITAS DIPONEGORO ANGKATAN 2014-2017
}

\author{
Gina Sakinah $^{1}$, Bagio Mudakir ${ }^{2}$ \\ Departemen IESP Fakultas Ekonomika dan Bisnis Universitas Diponegoro Jalan Prof. \\ Soedharto SH Tembalang, Semarang 50275 Telp.(024) 76486851, 76486853, Fax (024) \\ 76486852 \\ sakinahgina97@gmail.com
}

\begin{abstract}
Financial management failure occurs when students do not have good financial literacy. Students must have good knowledge, attitude, and behavior in managing their personal finances. This study aims to analyze the level of financial literacy of undergraduate students of the Faculty of Economics and Business at Diponegoro University class of 2014 to 2017 and the factors that influence it.

Financial literacy in this study uses a financial literacy index consisting of components of the knowledge, attitude, and financial behavior of students. The research data uses primary data with questionnaires and sample of 100 students. Meanwhile, the method used in this study is descriptive statistics and multiple linear regression test (OLS).

As a result, the level of student financial literacy is categorized as quite literary, that is 50.4\%, influenced by age, GPA, parental education, and length of study. On the other hand, gender and income do not affect student financial literacy.
\end{abstract}

Keywords: Financial Literacy, Financial Literacy Index, Financial Knowledge, Financial Attitudes, Financial Behavior.

JEL Classification: $G-4$.

\section{PENDAHULUAN}

Berawal dari adanya konsep human capital yang diperkenalkan oleh Theodore.W.Schultz pada tahun 1960 yakni suatu bentuk modal yang dapat menginvestasikan diri melalui berbagai bentuk investasi sumber daya manusia, diantaranya pendidikan formal, pendidikan informal. Dalam jurnal yang diterbitkan oleh The Journal of Consumer Affairs, salah satu komponen dari human capital adalah literasi keuangan. Menurutnya, literasi keuangan merupakan input yang ditujukan untuk meningkatkan human 
capital setiap individu dengan memiliki pengetahuan keuangan dan aplikasinya terhadap keuangan pribadi.

Kondisi tingkat literasi keuangan di Indonesia menurut penelitian dari Otoritas Jasa Keuangan masih tergolong rendah, pada tahun 2013 mencapai $21.84 \%$ dan tahun 2016 mencapai $29.66 \%$ dan tingkat literasi keuangan mahasiswa hanya mecapai $28.3 \%$. Menurut World Bank hal tersebut dikarenakan separuh dari penduduk Indonesia belum memiliki akses terhadap layanan jasa keuangan.

Rendahnya tingkat literasi keuangan dikalangan mahasiswa berdasarkan survei OJK menjelaskan bahwa sebagian besar mahasiswa masih belum memahami konsep keuangan, padahal seharusnya mahasiswa bisa secara mandiri mengatur keuangannya dengan baik dan bertanggung jawab atas keputusan keuangan yang mereka buat, karena bagi sebagian besar mahasiswa, masa perkuliahan adalah masa pertama mereka mengelola keuangannya sendiri tanpa pengawasan orangtua (sabri et.al)

Melihat keadaan tersebut, OJK berinisiatif membuat Strategi Nasional Literasi Keuangan (SNLK) sebagai upaya peningkatan literasi keuangan masyarakat Indonesia, khususnya mahasiswa dengan mamasukkan materi edukasi keuangan dalam kurlikulum Perguruan Tinggi. Undip adalah salah satu Perguruan Tinggi ternama yang ada di indonesia, yang juga mengemban tugas untuk mensukseskan SNLK sebagai perpanjangan tangan dari OJK. Salah satu fakultas yang terdapat di Universitas Diponegoro adalah fakultas ekonomika dan bisnis dimana bidang keilmuan ekonomi dan keuangan sebagai bahan ajar utamanya sehingga dianggap sudah memiliki tingkat literasi keuangan yang baik.

Tinggi rendahnya tingkat literasi keuangan mahasiswa dikarenakan oleh berbagai faktor. Adapun terkait faktor-faktor yang mempengaruhi tingkat literasi keuangan di kalangan mahasiswa itu sendiri menurut Chen dan Volpe (1998) menunjukkan bahwa disiplin akademis, jenis kelamin, etnis, dan pengalaman kerja merupakan faktor-faktor yang berhubungan dengan literasi keuangan, sedangkan Cude, et al (2006) menemukan adanya hubungan antara karakteristik demografi (jenis kelamin, etnis, status perkawinan orang tua, lama kuliah, IPK, kepemilikian kartu kresiti) dengan literasi keuangan mahasiswa.

Adanya permasalahan yang sudah dijelaskan, perlu diketahui bagaimana tingkat literasi keuangan mahasiswa S-1 Fakultas Ekonomika dan Bisnis Universitas Diponegoro Angkatan 2014-2017. Selain itu perlu diketahui apakah faktor jenis kelamin, usia, penghasilan, IPK, pendidikan orang tua dan lama studi mempengaruhi tingkat literasi keuangan mahasiswa.

\section{TINJAUAN PUSTAKA}

Literasi keuangan didefinisikan sebagai tingkat pengetahuan (knowledge) keterampilan (skill), keyakinan (confidence), yang mempengaruhi sikap (attitude) dan perilaku (behaviour) untuk meningkatkan kualitas pengambilan keputusan dan pengelolaan keuangan dalam rangka mencapai kesejahteraan. masyarakat luas tidak hanya mengetahui dan memahami lembaga keuangan serta produk dan jasa keuangan, melainkan juga dapat mengubah atau memperbaiki perilaku masyarakat dalam pengelolaan keuangan sehingga mampu meningkatkan kesejahteraan mereka (OJK,2017).

Atkinson and Messy, 2012. Indeks Literasi Keuangan adalah nilai yang diukur berdasarkan beberapa komponen dari literasi keuangan, yaitu pengetahuan keuangan (financial knowledge) yakni pengambilan keputusan individu yang menggunakan kombinasi dan beberapa keterampilan, sumber daya dan pengetahuan kontekstual untuk mengelola 
informasi dan membuat keputusan. Chen and Volpe (1998) menjabarkan pengetahuan keuangan ke dalam 4 dimensi yaitu pengetahuan umum keuangan pribadi, tabungan dan simpanan, asuransi dan investasi. Komponen kedua adalah sikap keuangan (financial attitude) yakni mengacu bagaimana seseorang bersikap atas keuangan pribadinya yang diukur dengan tanggapan atas sebuah pernyataan atau opini (Marsh, 2006). Menurut penelitian Brant A Marsh, sikap keuangan mahasiswa diukur dengan 4 indikoator, orientasi terhadadap keuangan pribadi, filsafat utang, keamanan keuangan dan menilai keuangan pribadi. Komponen terakhir adalah perilaku keuangan (financial behavior) yakni ilmu yang mempelajari tentang bagaimana manusia dalam mengambil suatu tindakan pada proses pengambilan keputusan dalam pengeloaan keuangan sebagai respon dan informasi yang diperolehnya. Menurut penelitian Brant A Marsh, perilaku keuangan mahasiswa diukur dengan 4 indikoator, pengroganisasian, pengeluaran, tabungan dan pemborosan. Indeks Literasi Keuangan ini digunakan untuk mengetahui tingkat literasi keuangan seseorang dan mengklasifikasikannya kedalam beberapa kategori, apakah seseorang tersebut termasuk kategori terliterasi rendah, terliterasi sedang atau terliterasi tinggi.

Berdasarkan penelitian dari Chen and Volpe (1998), ada pengaruh antara jenis kelamin terhadap tingkat literasi keuangan mahasiswa. Mahasiswa laki-laki memiliki tingkat literasi keuangan yang lebih tinggi dibandingkan perempuan. Laki-laki tidak banyak mempertimbangkan variabel-variabel yang berhubungan dengan keputusan keuangannya, karena karakter laki-laki yaitu sangat mandiri, sangat logis mudah membuat keputusan, tidak terlalu emosional, sangat percaya diri. Penelitian lain dari Margaretha dan Pambudhi, R. Arief (2015) menyatakan bahwa jenis kelamin mempengaruhi tingkat literasi keuangan mahasiswa, dimana mahasiswi perempuan memiliki tingkat literasi keuangan yang lebih tinggi dibandingkan mahasiswa laki-laki. Hasil penelitian Margaretha dan Pambudhi di dukung oleh hasil survei Bank Indonesia (BI) yang tertulis di media online Republika.co.id, Mulya Siregar (Direktur Stabilitas Sistem Keuangan BI) menjelaskan bahwa perempuan memiliki tingkat literasi keuangan yang lebih tinggi dibandingkan dengan laki-laki, karena perempuan lebih dominan dalam mengelola keuangannya

Berdasarkan penelitian dari Chen and Volpe (1998), ada pengaruh antara usia terhadap tingkat literasi keuangan mahasiswa, semakin tua mahasiswa maka semakin memiliki tingkat literasi keuangan yang tinggi. Hal ini menjelaskan bahwa semakin tinggi usia, dimana pengalaman hidup semakin banyak, informasi yang diperoleh semakin luas untuk memahami konsep keuangan, semakin dewasa pula dalam mengatur dan mengelola keuangan.

Kweon (2011) menjelaskan terdapat hubungan antara pendapatan dari orang tua dengan literasi keuangan. hal ini menunjukkan bahwa mahasiswa dengan pendapatan yang lebih tinggi cenderung memiliki tingkat literasi keuangan yang tinggi karena mereka lebih sering dan terbiasa menggunakan instrument dan layanan finansial.

Cude et al.(2006) menjelaskan bahwa mahasiswa yang memiliki IPK yang tinggi akan memiliki keuangan yang lebih sehat atau lebih baik, karena kecerdasan yang dimiliki mahasiswa menggambarkan seberapa paham mahahsiswa tersebut tentang konsep keuangan.

Dalam hal literasi keuangan, semakin tinggi tingkat pendidikan orang tua maka orang tua tersebut akan semakin paham dan terbiasa dengan segala bentuk produk dan jasa keuangan yang ada dan semakin mengerti bagaimana cara mengelola keuangan dengan bijak. Disini, peran orang tua sangat penting dalam mempengaruhi sikap dan perilaku seorang anak 
dalam hal mengelola keuangannya. Lusardi (2010) menemukan bahwa pendidikan dari orang tua merupakan hal yang besar pengaruhnya terhadap literasi keuangan.

Nababan dan Sadalian (2012) menjelaskan bahwa lamanya seseorang kuliah memberikan dampak positif terhadap tingkat literasi keuangan. mahasiswa senior memiliki lebih banyak pengalaman hidup dengan produk keuangan dan pengembangan pola perilaku keuangan yang baik.

\section{METODE PENELITIAN}

\section{Variabel Definisi Operasional dan Pengukuran}

Dalam penelitian ini, variabel dependen adalah indeks literasi keuangan mahasiswa, sedangkan variabel independennya adalah jenis kelamin, usia, pendapatan, ipk, pendidikan orangtua, lama studi

1. Indeks literasi keuangan, nilai indeks literasi keuangan adalah kombinasi dari kemampuan pengetahuan, sikap dan perilaku individu tentang konsep keuangan untuk membuat penilaian dan keputusan efektif mengenai penggunaan dan pengelolaan keuangan. Menurut OECD terdapat kombinasi dari tiga komponen indikator yang digunakan untuk mengukur besaran indeks literasi keuangan, yaitu:

a. Indeks pengetahuan keuangan, diukur dengan total skor jawaban responden yang benar dari skor total 20 pertanyaan terkait dengan pengetahuan umum keuangan pribadi, tabungan dan simpanan, asuransi, dan investasi.

b. Indeks sikap keuangan, diukur dengan total skor jawaban responden dari 12 pertanyaan terkait dengan konsep orientasi terhadap keuangan pribadi, filsafat utang, keamanan keuangan, dan menilai keuangan pribadi.

c. Indeks perilaku keuangan diukur dengan total skor jawaban responden dari skor total 12 pernyataan terkait dengan konsep pengorganisasian, pengeluaran , tabungan dan pemborosan.

Masing-masing komponen tersebut dihitung terlebih dahulu besaran indeksnya, sehingga bernilai kisaran antara 0 (tidak terliterasi) hingga 1 (terliterasi dengan baik)Teknik penyusunan indeks masing-masing komponen pada dasarnya mengikuti rumus sebagai berikut :

\section{Dimana :}

$$
\mathrm{ILK}=\sum_{i=1}^{3} \operatorname{Ii}: \operatorname{Ii}\left(\frac{X i-\operatorname{Min} X i}{\operatorname{Max} X i-\operatorname{Min} X i}\right)
$$

$$
\begin{array}{ll}
\text { ILK } & \text { :Indeks Literasi Keuangan } \\
\text { Ii } & : \text { Indeks komponen ILK ke } 1(\mathrm{i}=1,2,3) \\
\mathrm{Xi} & : \text { Nilai indikator komponen ILK ke 1 } \\
\text { Max Xi } & \text { : Nilai Maximum Xi } \\
\text { Min Xi } & \text { : Nilai Minimum Xi }
\end{array}
$$


Rumus yang digunakan untuk menghitung indeks literasi keuangan setiap mahasiswa adalah sebagai berikut :

$$
I L K=\frac{\text { Indeks } X_{1}+\text { Indeks } X_{2}+\text { Indeks } X_{3}}{3}
$$

Dimana :

$$
\begin{array}{ll}
\text { ILK } & : \text { Indeks Literasi Keuangan Mahasiswa } \\
\text { Indeks } X_{1} & : \text { Indeks Pengetahuan Keuangan } \\
\text { Indeks } X_{2} & : \text { Indeks Sikap Keuangan } \\
\text { Indeks } X_{3} & : \text { Indeks Perilaku Keuangan }
\end{array}
$$

Hasil dari indeks literasi keuangan mahasiswa kemudian dibagi kedalam beberapa kategori berdasarkan rumus Penilaian Acuan Norma (PAN) yakni adalah penilaian yang dilakukan dengan mengacu pada norma kelompok atau nilai yang diperoleh mahasiswa dibandingkan dengan nilai-nilai mahasiswa lain dalam kelompok tersebut. Pedoman yang digunakan untuk mengubah skor mentah menjadi skor standar pada PAN berdasarkan ratarata (mean) dan standar deviasi. Klasifikasi indeks literasi keuangan mahasiswa S-1 fakultas ekonomika dan bisnis universirtas diponegoro dijelaskan sebagai berikut:

\section{Tabel 1}

\section{Klasifikasi Tingkat Literasi Keuangan Mahasiswa}

\begin{tabular}{lcc}
\hline Nilai Indeks Literasi Keuangan & Klasifikasi & Justifikasi \\
\hline$>69,57$ & 1 & Terliterasi tinggi \\
$56,85-69,57$ & 2 & Terliterasi baik \\
$44,14-56.85$ & 3 & Terliterasi cukup \\
$31,42-44,14$ & 4 & Kurang terliterasi \\
$<31,42$ & 5 & Terliterasi rendah \\
\hline
\end{tabular}

2. Dummy jenis kelamin, menjelaskan klasifikasi responden berdasarkan perbedaan bentuk, sifat, dan fungsi biologis terbagi menjadi jenis kelamin dari laki-laki maupun perempuan yang disimbolkan 1 untuk responden berjenis kelamin laki-laki, dan 0 untuk responden perempuan.

3. Usia, menjelaskan umur dari responden saat ini.

4. Penghasilan, menjelaskan berapa besar penghasilan yang diterima dari orangtua dalam periode satu bulan dengan kategori (1) < Rp.1.000.000, (2) Rp. $1.000 .000-$ Rp.1.500.000, (3) Rp. 1.500.000 - Rp.2.000.000, (4) > Rp. 2.000.000.

5. IPK, menjelaskan besaran indeks prestasi komulatif dari responden saat ini dengan kategori (1) $<2.50$ (2) 2.50 - 3.00 (3) $3.00-3.50$ (4) $>3.50$.

6. Pendidikan orang tua, ini menjelaskan jenjang Pendidikan terakhir yang di tempuh oleh orang tua responden yang dikelompokkan menjadi tujuh kategori, yakni: (1) SD, (2) SMP, (3) SMA, (4) Diplomat, (5) Sarjana, (6) Magister, (7) Doktor 
7. Lama studi, menjelaskan lama waktu responden menempuh pendidikan sejak awal masa perkuliahan dalam satuan tahun.

\section{Populasi dan Sampel}

Populasi pada penelitian ini adalah mahasiswa program sarjana (S1) jurusan Ilmu Ekonomi dan Studi Pembangunan, Manajemen, Akuntansi, dan Ekonomi Islam Universitas Diponegoro Aktif angkatan 2014-2017 baik laki-laki maupun perempuan sejumlah 2417 mahasiswa. Penentuan sampel minimal dengan rumus slovin dengan hasil sampel 100 responden.

\section{Teknik Pengambilan Sampel}

Teknik pengambilan sampel pada penelitian ini menggunakan teknik proportional stratified random sampling karena populasi dalam penelitian ini tidak homogen dan berstrata proporsional. Alokasi sampel untuk masing-masing jurusan dan angkatan sebagai berikut :

Tabel 2

Alokasi Sampel

\begin{tabular}{|c|c|c|c|c|c|}
\hline \multirow{2}{*}{ Jurusan } & \multicolumn{4}{|c|}{ Angkatan } & \multirow{2}{*}{ Tota } \\
\hline & 14 & 15 & 16 & 17 & \\
\hline IESP & 5 & 6 & 6 & 7 & 24 \\
\hline Menejemen & 7 & 9 & 9 & 10 & 35 \\
\hline Akuntansi & 5 & 6 & 6 & 7 & 29 \\
\hline $\begin{array}{l}\text { Ekonomi } \\
\text { Islam }\end{array}$ & 1 & 2 & 4 & 5 & 12 \\
\hline
\end{tabular}

\section{Metode Pengumpulan Data}

Data diperoleh melalui pengisian kuesioner oleh mahasiswa S-1 jurusan Manajemen, Akuntansi, IESP dan Ekonomi Islam FEB UNDIP angkatan 2014 - 2017. Jenis kuesioner yang digunakan adalah kuesioner tertutup, yakni daftar pertanyaan yang alternatif jawabannya telah disediakan oleh peneliti sehingga responden hanya dapat memberikan tanggapan terbatas pada pilihan yang diberikan.

Kuesioner dibagi dua bagian, pertama berisi data karakteristik responden yang terdiri dari nama, jenis kelamin, usia, angkatan, jurusan, pendapatan, ipk, dan pendidikan orangtua. Kedua, berisi pertanyaan dan pernyataan yang berkaitan dengan literasi keuangan untuk mengetahui tingkat literasi keuangan mahasiswa.

Pada bagian ini, terbagi menjadi 3 section, pertanyaan kuesioner untuk bagian pengetahuan keuangan terdiri dari 20 soal yang berkaitan dengan pengetahuan keuangan mengacu pada penelitian Chen and Volpe (1998). Responden memilih jawaban yang dianggap benar dan mendapat poin 1 untuk jawaban benar, dan 0 untuk jawaban salah.

Selanjutnya kuesioner untuk bagian sikap dan perilaku keuangan mengacu pada penelitian Brant.A.Marsh (2006) terdiri dari 12 pertanyaan. Pengukuran komponen sikap keuangan dan perilaku keuangan diukur menggunakan skala likert. Skala likert digunakan untuk mengukur sikap, pendapatan dan persepsi seseorang maupun kelompok mengenai 
suatu fenomena sosial. Skala likert yang digunakan adalah skala likert 5 point dengan justifikasi sebagai berikut:

Tabel 3

Skala Likert Sikap Keuangan dan Perilaku Keuangan

\begin{tabular}{lllc}
\hline & & \multicolumn{2}{c}{ Skala Likert } \\
Sikap & Perilaku & Pernyataan Positif & $\begin{array}{c}\text { Pernyataan } \\
\text { Negatif }\end{array}$ \\
\cline { 1 - 2 } Sangat Tidak Setuju & Tidak & 1 & 5 \\
Tidak Setuju & Pernah & 2 & 4 \\
Kurang Setuju & Jarang & 3 & 3 \\
Setuju & Biasanya & 4 & 2 \\
Sangat Setuju & Sering & 5 & 1 \\
\hline
\end{tabular}

\section{Metode Analisis}

Metode analisis data pada penelitian ini menggunakan metode analisis data kuantitatif untuk menganalisis tingkat literasi keuangan mahasiswa dan faktor-faktor yang mempengaruhi tingkat literasi keuangan mahasiswa S-1 FEB UNDIP angkatan 2014-2017.

Penelitian ini menggunakan alat pengolahan data dengan menggunakan aplikasi software IBM SPSS Statistics 23 yang digunakan untuk menguji hipotesis yang telah dikemukakan dengan analisis statistik deskriptif dan regresi linear berganda.

\section{Model Estimasi}

$$
Y=b_{0}+b_{1} \text { dummy } X_{1}+b_{2} X_{2}+b_{3} X_{3}+b_{4} X_{4}+b_{5} X_{5}+b_{6} X_{6}+e
$$

Keterangan:

$$
\begin{array}{ll}
\mathrm{Y} & =\text { Literasi Keuangan Mahasiswa } \\
\text { dummy } X_{1} & =\text { Dummy Jenis Kelamin } \\
X_{2} & =\text { Usia } \\
X_{3} & =\text { Penghasilan } \\
X_{4} & =\text { IPK } \\
X_{5} & =\text { Pendidikan Orangtua } \\
X_{6} & =\text { Lama Studi } \\
b_{0}-b_{6} & =\text { Koefisien Estimasi } \\
e & =\text { error }
\end{array}
$$




\section{HASIL PENELITIAN DAN PEMBAHASAN}

\section{Karakteristik Responden}

Identifikasi karakteristik responden dalam penelitian ini terdiri dari jenis kelamin, usia, penghasilan, IPK, pendidikan orangtua dan lama studi pada mahasiswa aktif S-1 Fakultas Ekonomika dan Bisnis Universitas Diponegoro angkatan 2014 - 2017.

Berdasarkan Tabel 4, mayoritas responden berjenis kelamin laki-laki, berusia 18 tahun, berpenghasilan rendah, memiliki IPK tinggi, latar belakang pendidikan orang tua SMA dan Sarjana, dan lama studi 1 tahun.

Tabel 4

Karakteristik Responden

\begin{tabular}{|c|c|c|c|}
\hline Variabel & Kategori & Frekuensi & $\%$ \\
\hline Jenis & Laki-Laki & 48 & 48 \\
\hline kelamin & Perempuan & 52 & 52 \\
\hline \multirow{6}{*}{ Usia } & 23 & 1 & 1 \\
\hline & 22 & 15 & 15 \\
\hline & 21 & 16 & 16 \\
\hline & 20 & 18 & 18 \\
\hline & 19 & 36 & 36 \\
\hline & 18 & 14 & 14 \\
\hline \multirow{4}{*}{ Penghasilan } & Penghasilan Rendah (< Rp.1.000.000) & 44 & 44 \\
\hline & $\begin{array}{l}\text { Penghasilan Cukup (Rp.1.000.000- } \\
\text { Rp.1.500.000) }\end{array}$ & 34 & 34 \\
\hline & $\begin{array}{l}\text { Penghasilan Sedang (Rp.1.500.000 - } \\
\text { Rp.2.000.000) }\end{array}$ & 13 & 13 \\
\hline & Penghasilan Tinggi (> Rp.2.000.000) & 9 & 9 \\
\hline \multirow{4}{*}{ IPK } & IPK Rendah $(<2,5)$ & 1 & 1 \\
\hline & IPK Cukup $(2,5-3,0)$ & 14 & 14 \\
\hline & IPK Baik $(3,0-3,5)$ & 42 & 42 \\
\hline & IPK Tinggi $(>3,5)$ & 43 & 43 \\
\hline \multirow{7}{*}{$\begin{array}{c}\text { Pendidikan } \\
\text { Orangtua }\end{array}$} & SD & 2 & 2 \\
\hline & SMP & 9 & 9 \\
\hline & SMA & 33 & 33 \\
\hline & Diploma & 10 & 10 \\
\hline & Sarjana & 31 & 31 \\
\hline & Magister & 12 & 12 \\
\hline & Doktor & 3 & 3 \\
\hline \multirow{4}{*}{$\begin{array}{c}\text { Lama } \\
\text { Perkuliahan } \\
\text { (Tahun) }\end{array}$} & 1 & 31 & 31 \\
\hline & 2 & 27 & 27 \\
\hline & 3 & 25 & 25 \\
\hline & 4 & 17 & 17 \\
\hline
\end{tabular}




\section{Tingkat Literasi Keuangan Mahasiswa}

Tingkat literasi keuangan mahasiswa S-1 FEB UNDIP dapat dilihat pada Tabel 5. Berdasarkan pengkategorian tersebut, rata-rata mahasiswa termasuk kategori cukup terliterasi sebesar 0.504 atau $50.4 \%$. Nilai indeks minimum 0.222 atau $22.2 \%$ dan nilai indeks maksimum 0.778 atau $77.8 \%$. Nilai standar deviasi dari rata-rata literasi keuangan bernilai 0.127 atau $12.7 \%$ dapat diketahui bahwa jawaban dari responden bervariasi.

Tabel 5

Tingkat Literasi Keuangan Mahasiswa

\begin{tabular}{lc}
\hline \multicolumn{1}{c}{$\begin{array}{c}\text { Statistik } \\
\text { Deskriptif }\end{array}$} & ILK \\
\hline Minimum & 0.222 \\
Maximum & 0.778 \\
Mean & 0.504 \\
Standar Deviasi & 0.127 \\
\hline
\end{tabular}

Berdasarkan hasil penelitian, dapat dilihat dari Tabel 6, menunjukkan bahwa mayoritas mahasiswa S-1 FEB Undip angkatan 2014-2017 memiliki tingkat literasi keuangan pada kategori terliterasi cukup yakni sebanyak 41 mahasiswa atau $41 \%$. Selanjutnya mahasiswa yang memiliki tingkat literasi keuangan dengan kategori tinggi berjumlah 8 mahasiswa, kategori tingkat literasi baik sebanyak 21 mahasiswa, sedangkan sebanyak 22 mahasiswa termasuk kategori kurang terliterasi, dan hanya 8 mahasiswa yang temasuk kategori literasi rendah.

\section{Tabel 6}

Kategori Tingkat Literasi Keuangan Mahasiswa

\begin{tabular}{lcc}
\hline \multirow{2}{*}{ Kategori } & \multicolumn{2}{c}{ Literasi Keuangan Mahasiswa } \\
\cline { 2 - 3 } & Jumlah & \% \\
\hline Terliterasi tinggi & 8 & 8 \\
Terliterasi baik & 21 & 21 \\
Terliterasi cukup & 41 & 41 \\
Kurang terliterasi & 22 & 22 \\
Terliterasi rendah & 8 & 8 \\
\hline \multicolumn{1}{c}{ Total } & 100 & 100 \\
\hline
\end{tabular}


Jurnal Dinamika Ekonomi Pembangunan

Tabel 7

Tingkat Literasi Keuangan Perkomponen

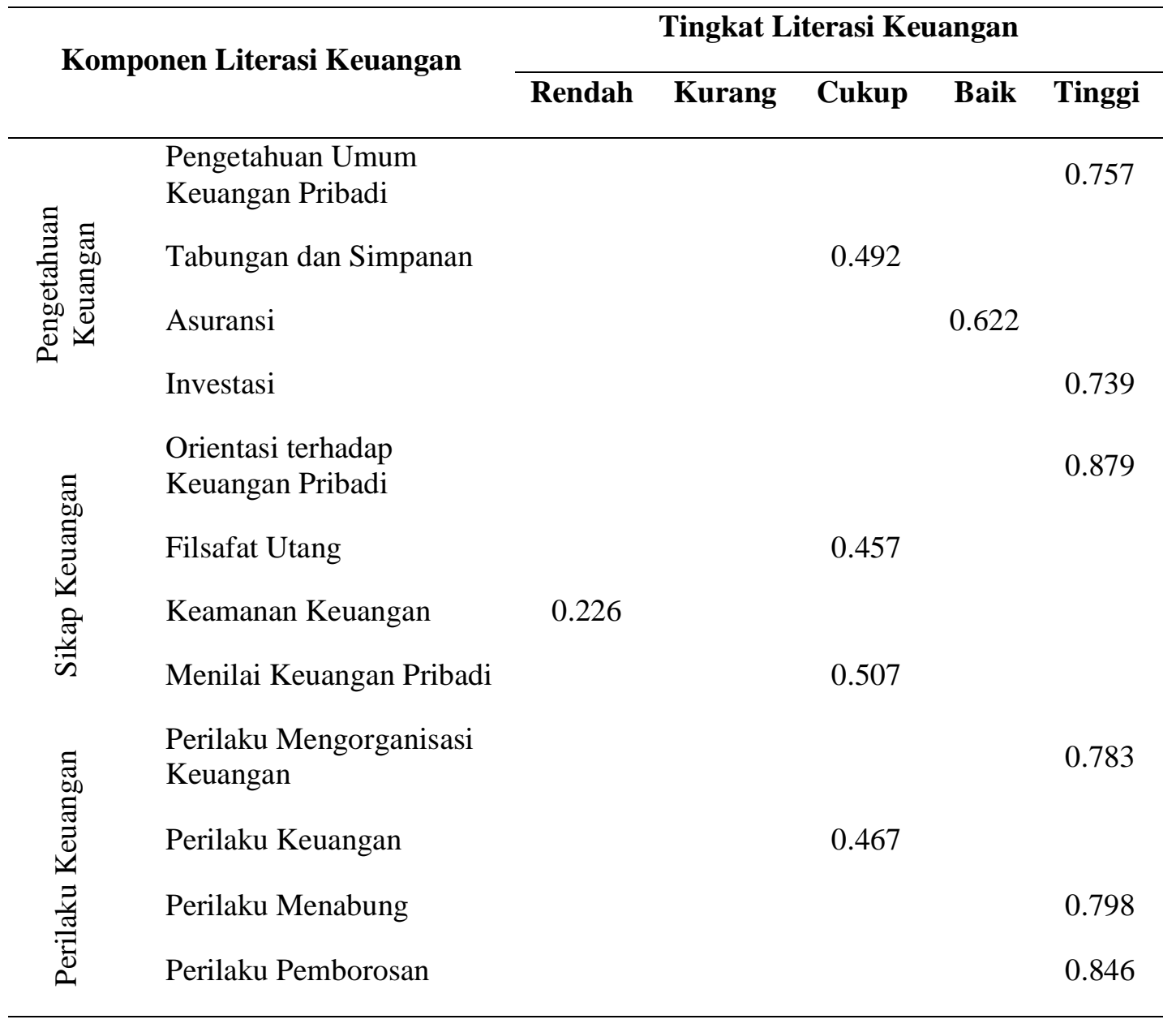

Tabel 7 menunjukkan tingkat literasi keuangan mahasiswa perkomponen literasi keuangan. Pada komponen pengetahuan keuangan, rata-rata mahasiswa terliterasi tinggi di aspek pengetahuan umum keuangan pribadi dan investasi. Terliterasi baik di aspek asuransi dan cukup terliterasi di aspek tabungan simpanan. Dapat disimpulkan bahwa pemahaman dan pengetahuan mahasiswa mengenai konsep keuangan sudah baik tetapi pada bagian tabungan dan simpana, banyak mahasiswa yang sudah paham akan konsep tabungan, tetapi kurang pemahaman tentang konsep pinjaman yang berhubungan dengan penggunaan kredit, penetapan bunga kredit. Hal itu disebabakan karena sedikit dari mahasiswa yang menggunakan kredit untuk menunjang kebutuhan hidupnya. Mereka berfikir belum sepenuhnya membutuhkan jasa kredit. Tetapi lebih baik jika memiliki pengetahuannya terlebih dahulu, agar saat membutuhkan, mahasiswa sudah mengerti bagaimana mekanisme dalam konsep pinjaman.

Komponen sikap keuangan, rata-rata mahasiswa terliterasi tinggi di aspek orientasi terhadap keuangan pribadi. Cukup terliterasi di aspek filsafat utang dan menilai keuangan 
pribadi dan terliterasi rendah di aspek keamanan keuangan. Dapat disimpulkan bahwa sikap keuangan mahasiswa belum mencerminkan sikap keuangan yang baik Hal ini dikarenakan mahasiswa belum memikirkan apa saja risiko-risiko yang dihasaoi, karena sampai saat ini, untuk memenuhi kebutuhan hidup, mahasiswa masih bergantung kepada ornag tua.

Komponen perilaku keuangan, rata-rata mahasiswa terliterasi tinggi di aspek perilaku mengorganisasi keuangan, perilaku menabung dan pemborosan. Cukup terliterasi di aspek perilaku keuangan. Dapat disimpulkan bahwa mahasiswa sudah memiliki perilaku keuangan yang mencerminkan perilaku keuangan yang baik.

\section{Faktor - faktor yang Mempengaruhi Literasi Keuangan Mahasiswa}

Sebelum mengetahui faktor apa saja yang mempengaruhi tingkat literasi keuangan mahasiswa, terlebih dahulu melakukan Uji asumsi klasik, karena dalam model regresi perlu memperhatikan adanya penyimpangan-penyimpangan atas asumsi klasik. Asumsi-asumsi klasik yang harus dipenuhi yaitu asumsi, normalitas, multikolinearitas, dan heteroskedastisitas.

Tabel 8

\section{Uji Asumsi Klasik}

\begin{tabular}{lc}
\hline \multicolumn{1}{c}{ Uji Asumsi Klasik } & Sig \\
\hline $\begin{array}{l}\text { Uji Normalitas Kolmogorov- } \\
\text { Smirnov }\end{array}$ & 0.195 \\
$\begin{array}{l}\text { Uji Heteroskedastisitas Breusch- } \\
\text { Pagan }\end{array}$ & 0.056 \\
\hline $\begin{array}{l}\text { Uji Multikolinearitas } \\
\text { VIF }\end{array}$ & Tolerance \\
\hline Jenis Kelamin & 0.842 \\
$\begin{array}{l}\text { Usia } \\
\text { 6.606 }\end{array}$ & 0.151 \\
$\begin{array}{l}\text { Penghasilan } \\
1.054\end{array}$ & \\
$\begin{array}{l}\text { IPK } \\
1.188 \\
\text { Pendidikan Orang tua } \\
1.6\end{array}$ & 0.949 \\
Lama Studi & 0.842 \\
7.28 & 0.625 \\
\hline
\end{tabular}

Hasil uji normalitas dengan Prob hitung sebesar 0.195 lebih besar dari alpha 0.05. oleh karena itu, dapat disimpulkan bahwa data residual pada model terdistribusi normal.

Hasil uji multikolinearitas dapat dilihat bahwa variabel yang digunakan sebagai predictor model regresi menunjukkan nilai VIF yang lebih kecil dari pada yang ditetapkan 
yaitu maksimal 10. Hal ini berartti bahwa variabel-variabel penelitian tidak menunjukkan adanya gejala multikolinearitas dalam model regresi.

Hasil uji heteroskedastisitas dapat dilihat bahwa nilai Prob.Chi-sqared sebesar 0.056 dan lebih besar dari 0.05 (alpha 5\%). Sehingga dapat disimpulkan bahwa pada model tidak terdapat heteroskedastisitas.

Berdasarkan hasil pengolahan data dengan menggunakan regresi linear berganda yang terdapat dalam Tabel 9, untuk mengetahui apakah jenis kelamin, usia, penghasilan, IPK, pendidikan orang tua dan lama studi memiliki pengaruh terhadap literasi keuangan mahasiswa.

Nilai R-square sebesar 0.811 atau $81.1 \%$. Hal ini berarti bahwa variabel independen jenis kelamin, usia, penghasilan, ipk, pendidikan orang tua, dan lama studi mampu menjelaskan variasi variabel dependen indeks literasi keuangan mahasiswa S-1 FEB UNDIP adalah sebesar $81.1 \%$. Sedangkan sisanya sebesar $18.9 \%$ dipengaruhi oleh variabel lain yang tidak termasuk dalam penelitian.

F tabel di dapatkan sebesar 2.20 selanjutnya pada model indeks literasi keuangan diperoleh nilai $\mathrm{F}$ statistik sebesar 66,64 dengan signifikasi 0.000. Maka nilai tersebut dapat disimpulkan bahwa variabel independen secara bersama-sama berpengaruh terhadap variabel dependen, karena F hitung > F tabel.

Tabel 9

Hasil Estimasi OLS

\begin{tabular}{|c|c|c|}
\hline Variable & Coefficient & Sig. \\
\hline $\mathrm{C}$ & -0.248 & 0.206 \\
\hline $\mathrm{JK}$ & -0.003 & 0.831 \\
\hline Usia & 0.025 & 0.029 \\
\hline Penghasilan & 0.005 & 0.436 \\
\hline IPK & 0.020 & 0.018 \\
\hline $\mathrm{PO}$ & 0.011 & 0.031 \\
\hline LS & 0.063 & 0.000 \\
\hline R-squared & 0.811 & \\
\hline Adjusted R-squared & 0.799 & \\
\hline F-statistic & 66.64 & \\
\hline Sig.(F-statistic) & 0.0000 & \\
\hline
\end{tabular}


Berdasarkan data yang didapat, dengan menggunakan alpha 5\% dan nilai $\mathrm{df}=94$ maka diperoleh nilai t tabel sebesar 1.661. Variabel jenis kelamin tidak berpengaruh terhadap tingkat literasi keuangan mahasiswa karena nilai t statistik sebesar -0.215 nilai t statistik < nilai t tabel sebesar 1.661. Tidak terdapat pengaruh secara parsial dari variabel jenis kelamin mahasiswa terhadap tingkat literasi keuangan mahasiswa.

Variabel usia berpengaruh positif dan signifikan terhadap tingkat literasi keuangan mahasiswa karena nilai t statistik sebesar 2.221 nilai $\mathrm{t}$ statistik > nilai $\mathrm{t}$ tabel sebesar 1.661. Terdapat pengaruh positih dari variabel usia mahasiswa terhadap tingkat literasi keuangan mahasiswa.

Variabel penghasilan tidak berpengaruh terhadap tingkat literasi keuangan mahasiswa karena nilai $\mathrm{t}$ statistik sebesar 0.782 nilai $\mathrm{t}$ statistik < nilai $\mathrm{t}$ tabel sebesar 1.661. Tidak terdapat pengaruh secara parsial dari variabel pendapatan mahasiswa terhadap indeks literasi keuangan mahasiswa.

Variabel ipk berpengaruh positif dan signifikan terhadap tingkat literasi keuangan mahasiswa karena nilai t statistik sebesar 2.398 nilai t statistik > nilai t tabel sebesar 1.661. Terdapat pengaruh positif dari variabel ipk mahasiswa terhadap tingkat indeks literasi keuangan mahasiswa.

Variabel pendidikan orangtua berpengaruh positif dan signifikan terhadap tingkat literasi keuangan mahasiswa karena nilai t statistik sebesar 2.193 nilai t statistik > nilai t tabel sebesar 1.661. Terdapat pengaruh positif dari variabel pendidikan orangtua mahasiswa terhadap tingkat literasi keuangan mahasiswa.

Variabel lama studi berpengaruh positif dan signifikan terhadap tingkat literasi keuangan mahasiswa karen nilai t statistik sebesar 4.437 nilai t statistik > nilai t tabel sebesar 1.661. Terdapat pengaruh positih dari variabel lama studi mahasiswa terhadap tingkat literasi keuangan mahasiswa.

Adapun hasil analisis regresi jenis kelamin, usia, penghasilan, ipk, dan lama studi terhadap indeks literasi keuangan dapat dilihat pada Tabel 9 hasil estimasi output diperoleh persamaan sebagai berikut :

$$
\begin{gathered}
\text { ILK }=-0.248-0.003 \text { JenisKelamin }+0.025 \text { Usia }+0.005 \text { Penghasilan }+0.020 \mathrm{IPK}+ \\
\text { 0.011PendidikanOrangtua }+0.063 \text { LamaStudi }+e
\end{gathered}
$$

Berikut ini dijelaskan interpretasi atas hasil penelitian.

a. Jenis Kelamin

Hasil penelitian menunjukkan bahwa variabel jenis kelamin dengan nilai koefisien sebesar - 0.003 dengan nilai probabilitas 0.831. Ttidak memiliki pengaruh dan tidak signifikan pada tingkat signifikasi $(\alpha=5 \%)$. Hal ini menunjukkan bahwa mahasiswa berjenis kelamin laki-laki dan perempuan tidak memiliki pengaruh terhadap tinggi rendahnya tingkat indeks literasi keuangan mahasiswa. Hasil penelitian ini mendukung hasil temuan dari Nidar dan Bestari (2012), yang menunjukkan bahwa jenis kelamin tidak berpengaruh terhadap literasi keuangan mahasiswa. Hal ini menjelaskan tidak terdapat perbedaan literasi keuangan antara mahasiswa pria dan mahasiswa perempuan, karena baik mahasiswa laki-laki maupun perempuan dianggap sudah familiar dengan bentuk-bentuk pengelolaan keuangan dan 
produk-produk keuangan.baik dan sama-sama memiliki kepedulian terhadap keuangan pribadi mereka.

\section{b. Usia}

Usia dengan nilai koefisien sebesar 0.025 dan nilai probabilitas 0.029 memiliki pengaruh positif dan signifikan pada tingkat signifikasi $(\alpha=5 \%)$. Hal ini menunjukkan bahwa usia mempengaruhi tingkat literasi keuangan mahasiswa. Setiap penambahan usia mahasiswa sebesar satu satuan, maka tingkat indeks literasi keuangan mahasiswa akan naik sebesar $0.025 \%$. Semakin tinggi usia mahasiswa maka tingkat literasi keuangannya semakin baik dan semakin muda usia mahasiswa maka tingkat literasi keuangannya semakin rendah. semakin kurang terliterasi. Hasil penelitian ini didukung oleh penelitian Shaari et al (2013) menemukan bahwa usia mempengaruhi literasi keuangan mahasiswa. Hal ini menjelaskan bahwa mahasiswa yang berusia antara 18 tahun hingga 24 tahun secara konsisten menunjukkan tingkat literasi keuangan yang rendah. Alasan rendahnya tingkat literasi keuangan karena usia mahasiswa pada kategori 19 tahun kebawah menjadi mayoritas dalam penelitian ini, dan pada seusia mereka berada dalam tahap yang sangat awal dari siklus hidup finansial mereka dan tahap awal memasuki masa perkuliahan.

\section{c. Penghasilan}

Variabel penghasilan dengan nilai koefisien sebesar 0.005 dan nilai probabilitas 0.436 memiliki pengaruh tetapi tidak signifikan pada tingkat signifikasi $(\alpha=5 \%)$. Hal ini menunjukkan bahwa tinggi rendahnya tingkat literasi keuangan mahasiswa tidak tergantung dengan penghasilan mahasiswa itu sendiri. Meskipun penghasilan yang diterima oleh mahasiswa tinggi namun tidak mutlak pengetahuan mahasiswa dalam mengelola keuangan juga sejalan dengan penghasilan. Lusardi et.al (2010) menunjukkan bahwa penghasilan orangtua yang tinggi dimana penghasilan yang diterima mahasiswa juga tinggi, bukan merupakan prediktor tingginya tingkat literasi keuangan mahasiswa. Kurangnya peran keluarga dalam memberikan pengetahuan keuangan bagi keuangan anaknya, akan mempengaruhi bagaimana anak tersebut mengelola keuangannya.

\section{d. IPK}

Variabel IPK dengan nilai koefisien sebesar 0.020 dengan nilai probabilitas 0.018 .memiliki pengaruh positif dan signifikan pada tingkat signifikasi $(\alpha=5 \%)$. Hal ini menunjukkan bahwa IPK mempengaruhi tingkat literasi keuangan mahasiswa. Setiap penambahan IPK mahasiswa sebesar satu satuan, maka tingkat indeks literasi keuangan mahasiswa akan naik sebesar $0.020 \%$. Semakin tinggi IPK mahasiswa maka tingkat literasi keuangannya semakin baik dan semakin rendah IPK mahasiswa maka tingkat literasi keuangannya semakin rendah. Hasil penelitian ini sesuai dengan penelitian Cude et al. (2006), Nababan dan Sadalian (2012), Sabri et al. (2008), Margaretha dan Pambdhi (2015) yang menemukan adanya pengaruh positif variabel IPK mahasiswa dengan tingkat literasi keuangan mahasiswa. IPK dapat mencerminkan tingkat intelektual mahasiswa sehingga mahasiswa akan semakin baik dalam mengelola keuangan pribadinya. Semakin tinggi IPK mahasiswa makan mahasiswa tersebut memiliki pengelolaan keuangan yang lebih baik.

\section{e. Pendidikan Orang Tua}

Variabel pendidikan orang tua dengan nilai koefisien sebesar 0.011 dengan nilai probabilitas 0.031 memiliki pengaruh positif dan signifikan pada tingkat signifikasi $(\alpha=5 \%)$. Hal ini menunjukkan bahwa pendidikan orang tua mempengaruhi tingkat literasi keuangan 
mahasiswa. Setiap peningkatan latar belakang pendidikan orangtua mahasiswa sebesar satu satuan, maka tingkat indeks literasi keuangan mahasiswa akan naik sebesar $0.011 \%$. Semakin tinggi latar belakang pendidikan orangtua dari mahasiswa maka tingkat literasi keuangannya semakin baik dan semakin rendah latar belakang pendidikan orangtua dari mahasiswa maka tingkat literasi keuangannya semakin rendah. peran orang tua sangat penting dalam mempengaruhi sikap dan perilaku seorang anak dalam hal mengelola keuangannya. Lingkungan keluarga yang berpendidikan tinggi akan memberikan pengaruh terhadap kecerdasan, sikap, dan perilaku seseorang yang terlibat dalam keluarga tersebut, dalam hal ini anak begitupun sebaliknya. Hasil penelitian ini sesuai dengan penelitian Lusardi, Mitchell, and Curto (2010) menemukan bahwa pendidikan dari orang tua merupakan hal yang besar pengaruhnya terhadap literasi keuangan. Ansong dan Gyensare (2012) menemukan bahwa terdapat hubungan positif antara pendidikan ibu dari responden dengan tingkat literasi keuangan responden.

\section{f. Lama Studi}

Variabel lama studi dengan nilai koefisien sebesar 0.063 dengan nilai probabilitas 0.000 memiliki pengaruh positif dan signifikan pada tingkat signifikasi $(\alpha=5 \%)$. Hal ini menunjukkan bahwa lama studi mahasiswa dalam mengenyam pendidikan perguruan tinggi mempengaruhi tingkat literasi keuangan mahasiswa. Setiap peningkatan lama studi dari mahasiswa sebesar satu satuan, maka tingkat indeks literasi keuangan mahasiswa akan naik sebesar $0.063 \%$. Mahasiswa yang telah menempuh masa studi yang lebih panjang pada dasarnya telah mendapatkan ilmu dan pengetahuan dari mata kuliah yang berhubungan dengan pengetahuan keuangan. pengalaman mereka dalam mengelola keuangan yang baik menjadi alasan tingginya tingkat literasi keuangan mahasiswa dibanding dengan mahasiswa yang baru menempuh masa studi. Hasil penelitian ini sesuai dengan penelitian Nababan dan Sadalian (2012) menjelaskan bahwa lamanya seseorang kuliah memberikan dampak positif terhadap tingkat literasi keuangan. mahasiswa senior memiliki lebih banyak pengalaman hidup dengan produk keuangan dan pengembangan pola perilaku keuangan yang baik.

\section{KESIMPULAN}

Berdasarkan pembahasan dan hasil analisis yang telah diuraikan pada Bab IV, maka dapat ditarik kesimpulan sebagai berikut:

1. Tingkat literasi keuangan mahasiswa S-1 Fakultas Ekonomika dan Bisnis Universitas Diponegoro angkatan 2014-2017 berada pada kategori cukup terliterasi, yakni sebesar $50,4 \%$.

2. Mahasiswa memiliki tingkat literasi tinggi pada aspek pengetahuan umum keuangan pribadi, investasi, orientasi terhadap keuangan pribadi, perilaku mengorganisasi keuangan, perilaku menabung, dan perilaku pemborosan. Terliterasi baik pada aspek asuransi, cukup terliterasi pada aspek tabungan dan simpanan, filsafat utang, menilai keuangan pribadi, dan perilaku keuangan, dan terliterasi rendah pada aspek keamanan keuangan.

3. Tidak terdapat pengaruh dari variabel jenis kelamin terhadap indeks literasi keuangan mahasiswa S-1 Fakultas Ekonomika dan Bisnis Universitas Diponegoro angkatan 2014-2017.

4. Terdapat pengaruh dari variabel usia terhadap indeks literasi keuangan mahasiswa S-1 Fakultas Ekonomika dan Bisnis Universitas Diponegoro angkatan 2014-2017. 
5. Terdapat pengaruh dari variabel usia terhadap indeks literasi keuangan mahasiswa S-1 Fakultas Ekonomika dan Bisnis Universitas Diponegoro angkatan 2014-2017.

6. Terdapat pengaruh dari variabel ipk terhadap indeks literasi keuangan mahasiswa S-1 Fakultas Ekonomika dan Bisnis Universitas Diponegoro angkatan 2014-2017.

7. Terdapat pengaruh dari variabel pendidikan orangtua terhadap indeks literasi keuangan mahasiswa S-1 Fakultas Ekonomika dan Bisnis Universitas Diponegoro angkatan 2014-2017.

8. Terdapat pengaruh dari variabel lama studi terhadap indeks literasi keuangan mahasiswa S-1 Fakultas Ekonomika dan Bisnis Universitas Diponegoro angkatan 2014-2017.

\section{DAFTAR PUSTAKA}

Ansong, A., and Gyensare, M. A. (2012). Determinants of University Working-Student's Financial Literacy at The University of Cape Coast, Ghana. International Journal of Bussinis and Management, 7(9), 126-133.

Atkinson A, Messy F. 2012. Measuring Financial Literacy: Result of the OECD / International Network on Financial Education (INFE) Pilot Study [Working Paper]. [OECD] Organization for Economic Cooperation and Development. 15.

Chen, H., \& Volpe, R. P. (1998). An analysis of financial literacy among college students. Financial Services Review, 7(1), 107-128.

Cude, B., et.al. (2006). College Students and Financial Literacy: What They Know and What We Need to Learn. Proceedings of The Eastern Family Economics and Resource Management Association, Eastern Familiy Economics and Resources Management Association, pp. 102-109.

Keown, L.A. (2011). The Financial Knowledge of Canadians. Canadians Social Trends, 11(8), 30-39.

Lusardi, A, Mitchel, O S, (2009). Financial Literacy Among the Young: Evidence and Implications for Consumer Policy. In Pension Research Working Paper. Pension Research Council, University of Penyslavania.

Margaretha, F and Pambudhi, R.A. (2015). Tingkat Literasi Keuangan pada Mahasiswa S-1 Fakultas Ekonomi. Jurnal Manajemen dan Kewirausahaan. Vol 17, No. 1 hal 7685.

Marsh, Brant A. (2006). Examining The Personal Finance Attitude, Behaviours, And Knowledge Levels Of First-Year And Senior Student At Baptist Universities In The State Of Texas. Disertasi.

Nababan, D., \& Sadalia, I. (2012). Analisis personal financial literacy dan financial behavior mahasiswa strata I fakultas ekonomi Universitas Sumatera Utara.

OECD INFE. 2012. PISA 2012 Literacy Assesment Framework. [Report Paper]

Otoritas Jasa Keuangan. (2017). Strategi Nasional Literasi Keuangan Indonesia (Revisit 2017). www.ojk.go.id 
Remund, D.L. (2010). Financial Literacy Explicated: The case for a clear definition in an increasingly complex economy. The Journal of Consumer Affairs, 44(2), 276-295.

Sabri, M.F., MacDonald, M., Masud, J., Hira, T.K., Othman, Mohd. A., 2008. Financial Behaviour and Problem among College Student in Malaysia: Research and Edcation Implication. Consumer Interest Annual, 54, 166-170.

Shaari, et. al.. 2013. Financial literacy: A Study Among the University Student. Journal of Contemporary Research in Business, Volume 5 No 2. Hal. 279- 299. 